\title{
Quality Protein Maize Response to Nitrogen Rate and Plant Density in the Guinea Savanna Zone of Ghana
}

\author{
S. S. J. Buah ${ }^{1 *}$, L. N. Abatania ${ }^{1}$ and G. K. S. Aflakpui ${ }^{2}$ \\ ${ }^{1}$ CSIR-Savanna Agricultural Research Institute, P. O. Box 52, Nyankpla, Tamale, Ghana \\ ${ }^{2}$ CSIR-Crops Research Institute, P. O. Box 3785, Kumasi, Ghana \\ *Corresponding author; E-mail: ssbuah@yahoo.com
}

\begin{abstract}
Field experiments were conducted in the Guinea savanna ecology of Ghana to evaluate yield response of quality protein maize (Zea mays L.) hybrid to plant density and nitrogen $(\mathrm{N})$ fertilizer. The experiments were conducted at four locations on 16 farmers' fields in 2002 and 2003. Three $\mathrm{N}$ rates $(0,90$ and $135 \mathrm{~kg} / \mathrm{ha})$ were combined with three plant densities (50 000, 62500 and 71400 plants/ha) to constitute nine treatments which were tested in a randomized complete block design. Optimal $\mathrm{N}$ rate was not affected by plant density. There was no yield response to plant density. However, grain yield had a linear and quadratic response to $\mathrm{N}$ at all sites. Grain yield increases as a result of $90 \mathrm{~kg} \mathrm{~N} / \mathrm{ha}$ applied over the farmers' practice $(0 \mathrm{~kg} \mathrm{~N} / \mathrm{ha})$ at Tumu, Jirapa, Kpongu and Wa were 39\%, 85\%, 101\% and 303\% in 2002, respectively. Grain yield increases for the same rate and sites in 2003 were $31 \%, 83 \%, 63 \%$ and 51\%, respectively. Marginal rate of return (MMR) to 90 $\mathrm{kg} \mathrm{N} / \mathrm{ha}$ combined with 62600 plants/ha was the highest (5564\%). Increasing N rate beyond $90 \mathrm{~kg} / \mathrm{ha} \mathrm{did} \mathrm{not}$ result in corresponding increase in yield nor net benefit to merit the extra cost that may be incurred. From the study, application of $90 \mathrm{~kg} \mathrm{~N} / \mathrm{ha}$ to hybrid maize would give economic yield response and acceptable returns at low risk to farmers, regardless of plant density.
\end{abstract}

\section{Introduction}

Maize (Zea mays L.) is a major cereal crop in Ghana. Typical maize grain yield from farmers' fields in the northern Guinea savanna zone is estimated at $1.2 \mathrm{t} / \mathrm{ha}$ as against a national average yield of $1.5 \mathrm{t} / \mathrm{ha}$ (SRID, MOFA, 2007). With good agronomic practices, improved maize varieties have the potential to produce $4-6 \mathrm{t} / \mathrm{ha}$ of grain. Most maize in developing countries is produced under low $\mathrm{N}$ conditions (McCown et al., 1992; Stoorvogel et al., 1993) because of low $\mathrm{N}$ status of tropical soils, low $\mathrm{N}$ use efficiency in drought-prone environments, high price ratios between fertilizer and grain, limited availability of fertilizer and low purchasing power of farmers (Bänziger $e t$ al., 1997). Subsistence farming in sub-
Saharan Africa, in general, is, thus, characterized by low external input, low crop yield, food insecurity, nutrient mining and environmental degradation (Stoorvogel et al., 1993; Rhodes, 1995; Mafongoya et al., 2006). Strategies must, therefore, be developed to restore soil fertility, to reduce erosion and environmental degradation in order to increase food production and alleviate chronic hunger in the zone (Vagen et al., 2005).

In the past, long fallow periods of 5-10 years allowed natural restoration of soil fertility. The fallow period has decreased in length or is almost nonexistent in many farming communities in the zone because of pressure on land to increase food production and other socioeconomic 
activities. Albert (1994) reported that $90 \%$ of all the fields in northern Ghana did not receive any mineral fertilizers in 1993 and it seems the trend has not changed significantly. Nutrient inputs from chemical fertilizers are needed to replace nutrients, which are exported and lost during cropping, to maintain a positive nutrient balance. As most farmers in this zone have low income, technical packages to increase and sustain agricultural production must be affordable, profitable and applicable to ensure their acceptability.

The recommended fertilizer rate for crop production depends on the agro-ecology, soil type and cropping history of the field. The recommended fertilizer rate for hybrid maize in the forest zone of Ghana is $134-56-56 \mathrm{~kg} /$ ha as $\mathrm{N}, \mathrm{P}_{2} \mathrm{O}_{5}$ and $\mathrm{K}_{2} \mathrm{O}$ for land which is continuously cropped (Aflakpui et al., 2005a). Additionally, intermediate maturing maize is grown at a plant density of 62,500 plants/ha. Traditionally, farmers use low plant densities as their adaptation to low soil fertility and soil moisture, and a means of minimizing risk during drought. Currently, various Non-Governmental Organizations (NGOs) are promoting the production of quality protein maize (QPM) hybrid to boost maize production in the Guinea savanna ecology. However, the optimum $\mathrm{N}$ fertilizer requirements and plant population have not been determined for the maize hybrid, Mamaba, in the zone.

Research has demonstrated the importance of inorganic fertilizer in crop production (Buah et al., 1998; Workayehu, 2000; Yamoah et al., 2002; Aflakpui et al., 2005b; Conley et al., 2005). Response to fertilizer is dependent on amount and distributions of moisture, soil fertility and variety. Hassan et al. (1998) have observed that due to differences in agro-climatic conditions, soil type and farmer groups, potential productivity gains from fertilizer use on small-scale farms are bound to vary, hence, the need for careful targeting of fertilizer recommendations. Broad or blanket fertilizer recommendations that assume homogeneity of farming conditions have, thus, partly contributed to the low diffusion of fertilizer technologies within the smallscale farm sector.

Various studies indicate that optimum fertilizer and plant populations provide better crop growth and yield. Nitrogen demand may also increase as plant density increases. The relationship between plant density and yield of cereals has been studied extensively, but conflicting reports have led to a renewed interest in the effects of high plant densities on yield of cereals (Workayehu 2000; Ma et al., 2003). Conley et al. (2005) showed that crop yield response to row spacing was variable and dependent upon environment. High plant densities increased cereal crop yield when compared to the recommended plant density in some studies (von Qualen et al., 1993; LaFarge \& Hammer, 2002; Conley et al., 2005). Other researchers found that plant density had no effect on maize grain yield (Ma et al., 2003; Aflakui et al., 2005b; Shapiro \& Wortmann, 2006). Combined use of fertilizer and optimum plant density may increase food production and safeguard the environment for future generation.

Mamaba is a three-way cross QPM hybrid which has a maturity classification of 105-110 days (Twumasi-Afriyie et al., 1997) and was released by Crops Research Institute, Kumasi, located in the forest zone 
of Ghana. Mamaba has superior nutritional quality compared to the normal maize varieties. It contains nearly twice as much usable protein as other normal maize grown in the country and yields more grain than traditional varieties of maize. The QPM produces $70-100 \%$ more of lysine and tryptophan than most modern varieties of tropical maize. Protein deficiency among children is common in northern Ghana where meat, fish and eggs are beyond the means of the average family with low incomes. Thus, the adoption and utilization of QPM may be a way of alleviating malnutrition, particularly in children. Cognizant of the need to identify lower fertilizer rates for lowincome farmers and the urgency of raising on-farm maize productivity on small-scale farms, the study tested a range of possible alternatives with specific objective of selecting economically appropriate $\mathrm{N}$ rate and plant density.

\section{Materials and methods}

Field experiments were conducted for 2 years at four on-farm locations (Wa, Kpongu, Jirapa and Tumu) with four farmers per location during the rainy season of 2002 and 2003. The 32 farmers' fields (i.e. 16 fields each year) were spread across the Upper West Region (UWR), which is located in the Guinea savanna zone of Ghana. The sites were representative of the soils and environmental conditions used for maize production in the Region, and the farmers were selected with due consultation with the extension staff of the Ministry of Food and Agriculture (MOFA). The study area is a semi-arid region, characterized by low, erratic, and poorly distributed monomodal rainfall, averaging about $1100 \mathrm{~mm}$ per annum. Most of the rain in the area come as short duration high intensity storms between May and October. Mean monthly temperatures during the growing season ranged between 26 and $30^{\circ} \mathrm{C}$. The soils in the Region have a sandy texture, inherently low in natural fertility and a low moisture retention capacity. The predominant soils of most of the farms, which are mostly derived from granite overlying Birrimian rocks, are sandy loam (classified as typic-plinthic Paleustalf according to the US Soil Taxonomy) by texture within the $0-30 \mathrm{~cm}$ soil depth and, thus, well to moderately well drained.

A randomized complete block design with factorial arrangement of three plant densities (50 000, 62500 and 71400 plants/ha) and three $\mathrm{N}$ fertilizer rates $(0,90$, and $135 \mathrm{~kg} /$ ha) was used to evaluate the yield response of a QPM hybrid, Mamaba. The levels of $\mathrm{N}$ and plant densities were combined to constitute nine treatments. Each of the four farmers within a location represented a replicate. Plots were $5 \mathrm{~m}$ long and eight rows wide with a spacing between rows of 0.80 $\mathrm{m}$ and variable spacing between hills in a row of $0.50,0.40$ and $0.35 \mathrm{~m}$ corresponded to the targeted plant densities of 50000,62 500 and 71400 plants/ha, respectively. Intended populations were not achieved in every year.

In both years, the farmers planted between 26 June and 3 July. Three seeds were hand-sown per stand and 2 weeks after emergence, the seedlings were hand-thinned to two per stand to achieve the desired plant density for treatments. Prior to planting, soils were tilled using a tractor disc plough without harrowing. Since farmers commonly use little or no mineral fertilizer for crop 
production in the area, the no $\mathrm{N}$ treatment was the control representing the farmers' practice. A plant density of 62500 plants/ha was maintained as recommended for the Guinea savanna zone by the Savanna Agricultural Research Institute (SARI). Implementation of this study involved active participation by farmers who applied routine management under the facilitation of the research team.

All plots were fertilized each year with $40 \mathrm{~kg} \mathrm{P}_{2} \mathrm{O}_{5} /$ ha as triple superphosphate (TSP) at planting. With the 90 and $135 \mathrm{~kg}$ $\mathrm{N} /$ ha treatments, $\mathrm{N}$ fertilizer was applied as urea in two split doses to maximize $\mathrm{N}$ efficiency. Within 10 days after planting, a portion of the $\mathrm{N}$ (45 and $90 \mathrm{~kg} \mathrm{~N} / \mathrm{ha}$, respectively) was applied to the 90 and 135 $\mathrm{kg} / \mathrm{N}$ plots. A supplemental $45 \mathrm{~kg} \mathrm{~N} / \mathrm{ha}$ was applied to the $\mathrm{N}$ treated plots 5 weeks after planting to make up for the 90 and $135 \mathrm{~kg}$ $\mathrm{N} / \mathrm{ha}$ at a time when the plants started to grow rapidly and $\mathrm{N}$ demand was high. All fertilizers were applied in a subsurface band about $0.05 \mathrm{~m}$ to the side of the maize row. Planting, weed control, fertilizer applications and harvesting were done using hand tools.

Data were taken on days to $50 \%$ silk emergence, total biomass (above ground dry matter) yield, grain yield and yield components. Grain yield was determined from the centre two rows of each plot and adjusted to $150 \mathrm{~g} / \mathrm{kg}$ (15\%) water content. Biomass yield was based on samples dried to constant weight at $60{ }^{\circ} \mathrm{C}$. Data collected were subjected to analysis of variance (ANOVA) to establish treatment and the interactions effect on grain yield and yield components. Statistical analyses were performed with the Statistical Program SAS for Windows 9.1® (SAS Institute Inc., Cary,
NC, USA). Row spacing and N levels were treated as fixed effects and years as random effects. Main effects and all interactions were considered significant when $P \leq 0.05$. The statistical significant treatments of this experiment were subjected to economic analysis using the partial budget procedure to determine the treatment combination that would give acceptable returns at low risk to farmers (CIMMYT, 1988). Economic analysis was done using the prevailing market prices for inputs at planting and for outputs at the time the crop was harvested. All costs and benefits were calculated on hectare basis in Ghana cedis ( $\mathrm{GH} \notin / \mathrm{ha}$ ). The following concepts used in the partial budget analysis are defined as follows: 1. Mean grain yield is the average yield ( $\mathrm{kg} / \mathrm{ha}$ ) of each treatment in each year. 2. The gross benefit per ha is the product of field price of maize and the mean yield for each treatment. 3 . The total variable costs (TVC) is the sum of field cost of fertilizer and the cost of fertilizer application. 4 . The net benefit per ha (NB) for each treatment is the difference between the gross benefit and the total variable costs.

For each pair of treatments, a percent marginal rate of return (MRR) was calculated. The MRR\% between any pair of treatments denotes the return per unit of investment in fertilizer expressed as a percentage. To obtain an estimate of these returns the MMR was calculated, which is given by the following formula: MRR (between treatments, 1 and 2) $=$ [change in net benefit $\left(\mathrm{NB}_{2}-\mathrm{NB}_{1}\right) /$ change in TVC $\left.\left(\mathrm{TVC}_{2}-\mathrm{TVC}_{1}\right)\right] \times 100$. Thus, a MRR of $100 \%$ implies a return of one Ghana cedi on every Ghana cedi of expenditure in the given variable input. 


\section{Results and discussion}

Growth conditions and crop development Total precipitation for the growing season (June-October) at Wa, Jirapa and Tumu were 702, 910 and $1032 \mathrm{~mm}$ in 2002 (Table 1). Amount of rainfall for the same locations in 2003 were 945,923 and $829 \mathrm{~mm}$, respectively. Rainfall figures recorded for Jirapa were obtained from a meteorological station at Babile which is about $15 \mathrm{~km}$ west of Jirapa. In 2002, the rainfall at Wa was inadequate, particularly during the critical crop growth stages (tasseling, silking and grain filling). Rainfall distribution was more favourable at all sites in 2003. Grain yield was greater in 2003 than 2002, illustrating the influence of weather on crop response to $\mathrm{N}$ fertilizer. Rainfall amounts were lowest in October each year. There was significant heterogeneity of residual error variances between years $(P<0.05)$; hence, the data for both years are presented separately. In both 2002 and 2003 plant density and N levels showed no significant interaction for any parameter measured or calculated, indicating that the response of maize to $\mathrm{N}$ fertilizer was independent on the plant populations used in this study.

Plant density (row spacing) had significant effect on days to $50 \%$ silk emergence at Tumu in 2002, where silking was significantly delayed by high plant population density stress (Table 2). Biomass yield was not affected by row spacing in 2002, except at Tumu when biomass was decreased at the lowest plant density (row spacing of $0.80 \times$ $0.50 \mathrm{~m}$ ). Biomass yield of maize planted at the highest density (spacing of $0.80 \times 0.35$ m) was $30 \%$ greater than those planted at the lowest density at Tumu (Table 3). Biomass yield was affected by plant density in 2003 at Jirapa and Tumu. Biomass yield of maize planted at the highest density was $17 \%$ and $23 \%$ greater than those planted at the lowest density at Tumu and Jirapa, respectively.

Averaged across plant density, silking was significantly delayed by low $\mathrm{N}$ at Wa in 2002 as well as Kpongu and Jirapa in 2003 (Table 2). Applied $\mathrm{N}$ shortened the time from emergence to midsilk at Wa in 2002 and Jirapa in 2003. Fertilized plants produced silk

TABLE 1

Total monthly precipitation during the growing period of maize in 2002 and 2003.

\begin{tabular}{|c|c|c|c|c|c|c|}
\hline & $W a$ & Тити & Babile† & & & \\
\hline & 2002 & 2003 & 2002 & 2003 & 2002 & 2003 \\
\hline Month & & & $m m$ & & & \\
\hline June & 122 & 292 & 131 & 115 & 218 & 214 \\
\hline July & 240 & 91 & 274 & 180 & 239 & 153 \\
\hline August & 158 & 220 & 333 & 213 & 229 & 315 \\
\hline September & 140 & 273 & 185 & 279 & 158 & 169 \\
\hline October & 42 & 69 & 109 & 42 & 66 & 72 \\
\hline Total & 702 & 945 & 1032 & 829 & 910 & 923 \\
\hline
\end{tabular}

$\dagger$ Precipitation amounts were unavailable for the Jirapa location.

West African Journal of Applied Ecology, vol. 16, 2009 
TABLE 2

Effect of plant density and $N$ fertilizer on silking date of maize planted in 2002 and 2003

\begin{tabular}{|c|c|c|c|c|c|c|c|c|}
\hline & \multicolumn{3}{|c|}{2002} & \multicolumn{3}{|c|}{2003} & \multirow[b]{2}{*}{ Jirapa } & \multirow[b]{2}{*}{ Tumu } \\
\hline & $W a$ & Kpongu & Jirapa & TuтuWa & $W a$ & Kpongu & & \\
\hline & & & & days & & & & \\
\hline \multicolumn{9}{|l|}{ Plant spacing } \\
\hline $0.80 \times 0.50 \mathrm{~m}$ & 62 & 64 & 66 & 60 & 58 & 55 & 56 & 62 \\
\hline $0.80 \times 0.40 \mathrm{~m}$ & 63 & 64 & 66 & 62 & 59 & 56 & 56 & 62 \\
\hline $0.80 \times 0.35 \mathrm{~m}$ & 62 & 66 & 66 & 66 & 58 & 55 & 55 & 62 \\
\hline Lsd (0.05) & NS & NS & NS & 2 & NS & NS & NS & NS \\
\hline \multicolumn{9}{|l|}{ N level $(\mathrm{kg} / \mathrm{ha})$} \\
\hline 0 & 66 & 66 & 66 & 62 & 59 & 54 & 54 & 63 \\
\hline 90 & 60 & 62 & 66 & 62 & 58 & 56 & 56 & 62 \\
\hline 135 & 61 & 62 & 66 & 61 & 58 & 58 & 59 & 62 \\
\hline $\mathrm{N}$ linear & $* *$ & NS & NS & NS & NS & $*$ & $* *$ & NS \\
\hline $\mathrm{N}$ quadratic & $* *$ & NS & NS & NS & NS & NS & NS & NS \\
\hline $\mathrm{CV}(\%)$ & 3 & 3 & 3 & 6 & 2 & 3 & 1 & 2 \\
\hline Mean & 62 & 63 & 66 & 62 & 58 & 56 & 56 & 62 \\
\hline
\end{tabular}

$*, * *$, and NS $=$ significant at $5 \%$ and $1 \%$ probability levels and not significant, respectively

TABLE 3

Effect of plant density and $N$ fertilizer on aboveground biomass yield of maize planted in 2002 and 2003

\begin{tabular}{|c|c|c|c|c|c|c|}
\hline & \multicolumn{3}{|c|}{2002} & \multicolumn{3}{|c|}{2003} \\
\hline & $W a$ & Jirapa & Тити & $W a$ & Jirapa & Тити \\
\hline & & & $k g / h a$ & & & \\
\hline \multicolumn{7}{|l|}{ Plant spacing } \\
\hline $0.80 \times 0.50 \mathrm{~m}$ & 2750 & 3437 & 2372 & 3050 & 2613 & 2995 \\
\hline $0.80 \times 0.40 \mathrm{~m}$ & 3130 & 3750 & 2767 & 3283 & 2778 & 3198 \\
\hline $0.80 \times 0.35 \mathrm{~m}$ & 3208 & 3958 & 3076 & 3263 & 3202 & 3500 \\
\hline Lsd (0.05) & NS & NS & 342 & NS & 353 & 312 \\
\hline \multicolumn{7}{|l|}{$N$ level $(\mathrm{kg} / \mathrm{ha})$} \\
\hline 0 & 2809 & 2986 & 2302 & 2992 & 2539 & 2599 \\
\hline 90 & 3232 & 3576 & 2990 & 3346 & 3128 & 3495 \\
\hline 135 & 3049 & 4583 & 2924 & 3258 & 3027 & 3599 \\
\hline $\mathrm{N}$ linear & NS & $* *$ & $* *$ & NS & $* *$ & $* *$ \\
\hline $\mathrm{N}$ quadratic & * & $*$ & $*$ & * & $*$ & $* *$ \\
\hline $\mathrm{CV}(\%)$ & 21 & 16 & 19 & 20 & 20 & 11 \\
\hline Mean & 3029 & 3715 & 2738 & 3199 & 2881 & 3231 \\
\hline
\end{tabular}

$*, * *$, and NS $=$ significant at $5 \%$ and $1 \%$ probability levels and not significant, respectively 
5 days earlier than those that were not fertilized. Early silk production due to added $\mathrm{N}$ may have resulted from rapid growth of plant parts leading to early development of floral organelles. Stunted growth and N stress was visually observed on unfertilized maize plants. The leaves of maize plants that did not receive any fertilizer $\mathrm{N}$ were light yellowish-green; plant growth was slow and flowering was delayed. When $\mathrm{N}$ supply is limiting, leaves become the main source of remobilized $\mathrm{N}$ to the grain. With adequate $\mathrm{N}$, maize leaves are dark green.

Maize biomass yield increased with applied $\mathrm{N}$ in a quadratic manner at the three sites (Wa, Jirapa and Tumu) where biomass was measured (Table 3 ). In all years, the main effect of increasing $\mathrm{N}$ rate from 90 to $135 \mathrm{~kg} / \mathrm{ha}$ did not result in increase in biomass yield. Biomass production was less with the no fertilizer treatment than the 90 and $135 \mathrm{~kg} \mathrm{~N} / \mathrm{ha}$ rates. Compared to farmers' practice $(0 \mathrm{~kg} \mathrm{~N} / \mathrm{ha})$, the $90 \mathrm{~kg} \mathrm{~N} /$ ha rate resulted in increase of $15 \%, 20 \%$ and $30 \%$ more biomass production at Wa, Jirapa and Tumu in 2002, respectively. Increasing $\mathrm{N}$ application rate to $135 \mathrm{~kg} / \mathrm{ha}$ resulted in biomass yield increase over control by $9 \%, 27 \%$ and $53 \%$ at Wa, Tumu and Jirapa, respectively. In 2003, application of $90 \mathrm{~kg} \mathrm{~N} / \mathrm{ha}$ resulted in biomass yield increases of $12 \%, 23 \%$ and $34 \%$ over no $\mathrm{N}$ application at Wa, Jirapa and Tumu, respectively. Biomass yield increases due to the application of $135 \mathrm{~kg} \mathrm{~N} / \mathrm{ha}$ were $9 \%$, $19 \%$ and $38 \%$, respectively, for Wa, Jirapa and Tumu in 2003. The return of crop residue to the soil could increase soil organic matter content. Maize grown with low fertilizer inputs may produce crop residue, which are relatively deficient in $\mathrm{N}$, and, therefore, its incorporation into the soil can significantly depress crop yields due to immobilization of soil N.

\section{Grain yield}

Grain yield over the 2 years were generally lower than the potential yield (> $6.0 \mathrm{t} / \mathrm{ha}$ ) of the QPM hybrid due to weather effects on seedling emergence and establishment. Grain yield was not affected by interaction effects or by the main effects of plant density. The absence of $\mathrm{N}$ fertilizer level $\times$ plant density interaction for grain yield and yield components indicated that grain yield response to applied $\mathrm{N}$ and $\mathrm{N}$ rates for optimum yield were not affected by plant density, although it is expected that efficient use of $\mathrm{N}$ by hybrid maize may be improved with higher plant density.

Averaged across $\mathrm{N}$ rate, grain yield was similar among plant densities at all sites (Table 4). Thus, hybrid maize can be planted in the range of 50000 and 71400 plants/ha without significant yield reduction. Although not statistically significant, maize planted at highest density (spacing of $0.80 \times 0.35 \mathrm{~m}$ ) tended to produce more grain than those planted at the sub-optimal density of 50000 plants/ha (spacing of $0.80 \times 0.50 \mathrm{~m}$ ). From this study, the contribution of plant population to grain yield was minimal (4.2\%). These results differ from findings in other regions, where grain yield increased as plant density was increased (von Qualen et al., 1993; LaFarge \& Hammer 2002; Conley et al., 2005), but supported by the findings of others (Ma et al., 2003; Aflakpui et al., 2005b). The results suggest that hybrid maize was somewhat flexible to plant density and replanting may not be necessary in some situations. Grain yield response to plant 
density might have been different for other hybrids. Porter et al. (1997), however, found, in a study with six adapted, high yielding hybrids, that maize hybrids were similarly affected by plant density and row spacing.

The lack of significant plant density effect on maize yield may be due to intra- and intercompetition at higher plant density. Plant density is an efficient management tool for maximizing grain yield by increasing the capture of solar radiation within the canopy. Efficiency of conversion of intercepted solar radiation into economic yield is, however, limited by mutual shading and competition of plants. Plant populations greater than necessary may reduce the plants' ability to cope with moisture stress and produce plants with smaller stems which are more susceptible to lodging. The highest plant population consistently resulted in more barren plants per hectare, which averaged $3 \%$ in comparison with less than $1 \%$ for the lowest plant density. Increases in plant growth, kernels per ear and in kernel weight may help compensate for low plant populations. As a result of this compensatory power, grain yield in cereals is relatively insensitive to plant population (Anderson, 1986).

Averaged across plant density, grain yield increased with $\mathrm{N}$ rate at all sites in 2002 and 2003 with significant linear and quadratic responses, but maximum yields were usually achieved with $\mathrm{N}$ at $90 \mathrm{~kg} / \mathrm{ha}$ (Table 4). The linear and quadratic response of grain yield to increased $\mathrm{N}$ application rate agrees with the results of others (Workayehu, 2000; Aflakpui et al., 2005b). In 2002, the average grain yield based on $\mathrm{N}$ rate was 1060, 2114 and $2268 \mathrm{~kg} / \mathrm{ha}$ at 0,90 and $135 \mathrm{~kg} \mathrm{~N} / \mathrm{ha}$, respectively. Mean grain yield based on the same $\mathrm{N}$ rates was 1430, 2230 and $2377 \mathrm{~kg} /$ ha in 2003. Grain yield increase was a result of numerical increase in both ear numbers and ear weight from 0 to $90 \mathrm{~kg} / \mathrm{ha}$ applied $\mathrm{N}$. The 90 and $135 \mathrm{~kg} \mathrm{~N} / \mathrm{ha}$ rates gave similar grain yields that were significantly greater than the yields from the farmers' practice $(0 \mathrm{~kg} \mathrm{~N} / \mathrm{ha})$ each year reflected largely in the increase in ear numbers. The number of ears harvested from the $0 \mathrm{~kg} \mathrm{~N} /$ ha plots, on average, was significantly less than those harvested from the 90 and 135 $\mathrm{kg} \mathrm{N} / \mathrm{ha}$ plots (data not shown). This is because without adequate plant nutrients, many plants were barren. The weight of ears harvested from one hectare shows the same trend as number of ears.

Mean grain yield increases as a result of $90 \mathrm{~kg} \mathrm{~N} / \mathrm{ha}$ applied over the control treatment at Tumu, Jirapa, Kpongu and Wa were 39\%, $85 \%, 101 \%$ and $303 \%$ in 2002 , respectively. The response to $\mathrm{N}$ was greatest in Wa in 2002 when rainfall was erratic. The reason for a better yield under uneven distribution of rainfall could be that application of $\mathrm{N}$ increased leaf area expansion and, thus, photosynthetic activity, rooting volume and water use efficiency, which all contributed to better crop growth and development (Nielsen \& Halvorson, 1991; Sallah et al., 1998). Mean yield increases at Tumu, Jirapa, Kpongu and Wa in 2003 were 31\%, 83\%, $63 \%$ and $51 \%$, respectively. Across sites, the application of $90 \mathrm{~kg} \mathrm{~N} / \mathrm{ha}$ resulted in mean increases of $100 \%$ and $57 \%$ more grain in 2002 and 2003, respectively, while yield increases of $114 \%$ and $66 \%$ were obtained from the application of $135 \mathrm{~kg} \mathrm{~N} / \mathrm{ha}$. Increasing $\mathrm{N}$ application rate to $135 \mathrm{~kg} / \mathrm{ha}$ did not result in any significant yield increase over the $90 \mathrm{~kg} \mathrm{~N} / \mathrm{ha}$ rate in either year. 
TABLE 4

Effect of plant density and $N$ fertilizer on grain yield of maize planted in 2002 and 2003

\begin{tabular}{|c|c|c|c|c|c|c|c|c|}
\hline & \multicolumn{4}{|c|}{2002} & \multicolumn{4}{|c|}{2003} \\
\hline \multicolumn{9}{|c|}{$\mathrm{kg} / \mathrm{ha}$} \\
\hline \multicolumn{9}{|l|}{ Plant spacing } \\
\hline $0.80 \times 0.50 \mathrm{~m}$ & 1638 & 1166 & 1734 & 1913 & 1927 & 1949 & 2013 & 1507 \\
\hline $0.80 \times 0.40 \mathrm{~m}$ & 1855 & 1180 & 2011 & 2333 & 2080 & 2051 & 2318 & 1610 \\
\hline $0.80 \times 0.35 \mathrm{~m}$ & 2058 & 1397 & 2103 & 2378 & 2287 & 2490 & 2319 & 1672 \\
\hline Lsd (0.05) & NS & NS & NS & NS & NS & NS & NS & NS \\
\hline \multicolumn{9}{|l|}{ N level $(\mathrm{kg} / \mathrm{ha})$} \\
\hline 0 & 609 & 699 & 1152 & 1778 & 1562 & 1533 & 1370 & 1253 \\
\hline 90 & 2452 & 1406 & 2130 & 2469 & 2354 & 2504 & 2503 & 1637 \\
\hline 135 & 2489 & 1639 & 2566 & 2378 & 2378 & 2453 & 2778 & 1898 \\
\hline $\mathrm{N}$ linear & $* *$ & $* *$ & $* *$ & $* *$ & ** & * & $* *$ & ** \\
\hline $\mathrm{N}$ quadratic & $*$ & NS & NS & $* *$ & NS & NS & NS & $* *$ \\
\hline $\mathrm{CV}(\%)$ & 22 & 21 & 20 & 19 & 21 & 25 & 23 & 9 \\
\hline Mean & 1850 & 1248 & 1949 & 2208 & 2098 & 2163 & 2217 & 1596 \\
\hline
\end{tabular}

$*, * *$, and NS $=$ significant at $5 \%$ and $1 \%$ probability levels and not significant, respectively

Greater grain yield increases with the application of $90 \mathrm{~kg}$ N/ha when compared to $135 \mathrm{~kg} \mathrm{~N} / \mathrm{ha}$ rate meant that the $90 \mathrm{~kg} \mathrm{~N} /$ ha was probably adequate to meet the $\mathrm{N}$ requirements of hybrid maize in the savanna zone.

All plots received uniform application of $P$ fertilize, hence, the yield difference among the treatments, when averaged across plant densities, may be due to fertilizer $\mathrm{N}$ application. Although measurements on root growth were not done in this study, greater yields with $\mathrm{N}$ application probably were a result of improved leaf area expansion, greater nutrient availability from other $\mathrm{N}$ pools and/or stimulation of root growth and N uptake. Eghball \& Maranville (1993) found that the mean $\mathrm{N}$ influx of maize increased with increasing soil $\mathrm{N}$ supply. The increased yield with $\mathrm{N}$ application is supported by the findings of others who reported increases in grain yields of cereals with N application (Buah et al., 1998; Khosla et al., 2000; Workayehu, 2000; Yamoah et al., 2002; Aflakpui et al., 2005b; Conley et $a l ., 2005)$. The effect of $\mathrm{N}$ fertilizer application in improving soil fertility status and sustainable crop production is demonstrated in the increased grain yield recorded in this study. Grain yield was a function of dry matter production. As a result of $\mathrm{N}$ fertilizer additions, the hybrid probably produced more dry matter and had more stem carbohydrates available for translocation during grain fill.

Shortcomings of past soil fertility research in this zone include limited economic analysis of results and use of trial sites and management that poorly represented those of smallholder farmers. The soils used for this study are typical upland soils used for maize production in the Guinea savanna zone 
of Ghana. The recommended fertilizer rate for hybrid maize in the forest zone is 134$56-56 \mathrm{~kg} / \mathrm{ha}$ as $\mathrm{N}, \mathrm{P}_{2} \mathrm{O}_{5}$ and $\mathrm{K}_{2} \mathrm{O}$ for land which is continuously cropped (Aflakpui et al., 2005a). As no previous research work had been done on hybrid maize response to $\mathrm{N}$ rates and plant density in the area, a 'blanket' recommendation of $64-38-38 \mathrm{~kg} /$ ha as $\mathrm{N}, \mathrm{P}_{2} \mathrm{O}_{5}$ and $\mathrm{K}_{2} \mathrm{O}$ was being advocated by agricultural extension agents to farmers. This recommendation was based on experiment station results on open-pollinated maize varieties developed more that two decades ago and not specific to any agroecology system.

The present results suggest that the application of $90 \mathrm{~kg} \mathrm{~N} / \mathrm{ha}$ to hybrid maize in the savanna zone is economically attractive for the range of plant densities tested. This rate is less than the currently recommended $\mathrm{N}$ rate for hybrid maize in the forest zone but greater than the age-old fertilizer recommendation of $64-38-38 \mathrm{~g} / \mathrm{ha}$ as $\mathrm{N}$, $\mathrm{P}_{2} \mathrm{O}_{5}$ and $\mathrm{K}_{2} \mathrm{O}$. The need for high rates of $\mathrm{N}$ application to exploit the full yield potential of this hybrid is, thus, imperative. In this zone, soils are highly degraded and soil fertility depletion is already high, relatively small amount of crop residues and animal manures are produced, hence, mineral fertilizers will become the principal sources for building up nutrients in soils. The benefits to the greater society from higher fertilizer use include elimination of malnutrition, the achievement of food self sufficiency and the minimization of nutrient mining.

\section{Economic analysis}

Economic analysis was done on the combined results using the partial budget technique. When compared to the treatment combination of 62500 plants/ha and $90 \mathrm{~kg}$ $\mathrm{N} / \mathrm{ha}$, the $135 \mathrm{~kg} \mathrm{~N} / \mathrm{ha}$ rate irrespective of plant density had less net benefits but more total variable cost (Table 5). Dominance analysis led to the selection of the following four treatment combinations: low plant stand (50 000 plants/ha) with no applied $\mathrm{N}$ (farmers' practice), 62500 plants/ha with no applied N, 50000 plants/ha with $90 \mathrm{~kg}$ N/ha and 62500 plants/ha with $90 \mathrm{~kg} \mathrm{~N} / \mathrm{ha}$, which were ranked in increasing order of total costs that vary. It is apparent that even without N, maize planted at the recommended plant density of 62500 plants/ha (spacing of $0.80 \times 0.40 \mathrm{~m}$ ) gave MRR greater than $100 \%$ when compared to the sub-optimal plant density of 50000 plants/ ha. Thus, farmers in the savanna zone may plant hybrid maize at a plant density of 62500 plants/ha without $\mathrm{N}$ fertilizer provided the soil is fertile.

The application of $90 \mathrm{~kg} \mathrm{~N} / \mathrm{ha}$ consistently recorded the greatest net benefits and MRR (5564\%) at the recommended plant density of 62500 plants/ha. Thus, for hybrid maize, returns to fertilizer use is more than the $100 \%$ rate of return usually assumed to be the minimum required for small-scale farmers to adopt the type of technology widely. As a guide MRR of below $100 \%$ is considered low and unacceptable to farmers (CIMMYT, 1988). This is because such a return would not offset the cost of capital (interest) and other related transaction costs while still giving an attractive profit margin to serve as an incentive. Thus, the change from farmers' practice of no fertilizer application to the application of $90 \mathrm{~kg} \mathrm{~N} / \mathrm{ha}$, which gave more than $100 \%$ MRR, is a promising new practice for farmers under the prevailing price structure. This combination seemed an 


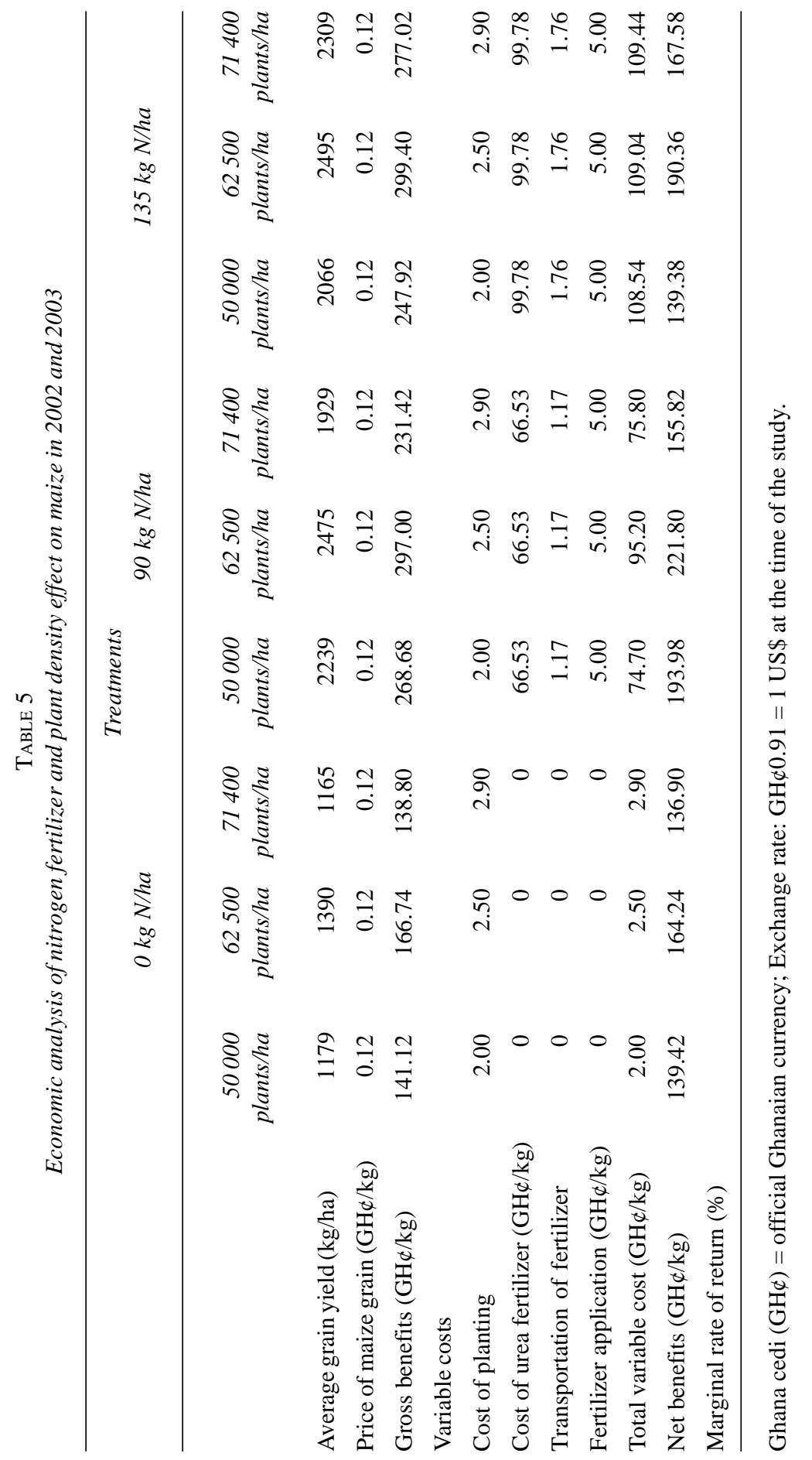

West African Journal of Applied Ecology, vol. 16, 2009 
optimum for resource-poor risk-averse farmers in the savanna zone. Results of the study showed that the $135 \mathrm{~kg} \mathrm{~N} / \mathrm{ha}$ rates obviously added to the cost of production, but did not add significantly to output. This is evidenced by the fact that increasing the $\mathrm{N}$ rate from 90 to $135 \mathrm{~kg} / \mathrm{ha}$, regardless of plant density, did not result in corresponding increase in grain yield or economic benefits to merit the extra cost that may be incurred.

\section{Conclusion}

Plant density did not affect response to applied N. Grain yield response to applied $\mathrm{N}$ and the optimum $\mathrm{N}$ application rates were generally similar for the range of plant densities tested. Optimal $\mathrm{N}$ rate was not affected by plant density, and plant density may not be a major determinate of $\mathrm{N}$ fertilizer requirements for maize. From the study, $\mathrm{N}$ fertilizer use on hybrid maize at 90 $\mathrm{kg} \mathrm{N} / \mathrm{ha}$ gave economic yield response and also provided higher returns at low risk to farmers in this zone, regardless of plant density. Tentatively, farmers in this zone could plant hybrid maize at the recommended plant density of 62500 plants $/$ ha with $90 \mathrm{~kg}$ $\mathrm{N} / \mathrm{ha}$ applied in two split doses. Increasing $\mathrm{N}$ rate to $135 \mathrm{~kg} \mathrm{~N} / \mathrm{ha}$ did not result in corresponding increase in grain yield, or economic benefits, to merit the extra production cost that may be incurred. The results of the study can be used to make tentative recommendations, which can be refined through multi-location testing over a wider area.

\section{Acknowledgement}

The authors are grateful to the Agricultural Services Sub-Sector Investment Programme (AgSSIP) for financial support of the research presented. They would also like to thank all the technical staff of SARI, Wa station and MOFA in Jirapa District and Wa municipality who assisted in data collection.

\section{References}

Anderson W. K. (1986). Some relationships between plant population, yield components and grain yield of wheat in a Mediterranean environment. Aust. $J$. Agric. Res. 37: 219-233.

Aflakpui G. K. S., Abdulai M. S., Berchie J. N., Ennin, S. and Sallah P. Y. K. (2005a). Maize production guide. Food Crops Development Project/Ministry of Food and Agriculture, Ghana. $45 \mathrm{pp}$.

Aflakpui G. K. S., Anchirinah V. M. and Asumadu H. (2005b). Response of a quality protein maize hybrid to $\mathrm{N}$ supply and plant density in the forest zone of Ghana. Trop. Sci. 45: 3-7. DOI: 10.1002/ ts.36.

Albert H. (1994). SARI Annual Report 2004. Savanna Agricultural Research Institute, Tamale, Ghana.pp. 190-202.

Bänziger M., Betran F. J. and Lafitte H. R. (1997). Efficiency of high nitrogen selection environments for improving maize for low nitrogen target environments. Crop Sci. 30: 556-561.

Buah S. S. J., Maranville J. W., Troare A. and Bramel-Cox P. J. (1998). Response of nitrogen use efficient sorghums to nitrogen fertilizer. J. Plant Nutr. 21: 2303-2318.

CIMMYT (1988). From agronomic data to farmer recommendations: An economics training manual. Completely revised edition. Mexico: DF. ISBN 968-6127-18-6

Conley S. P., Steven W. G. and Dunn D. D. (2005). Grain sorghum response to row spacing, plant density and planter skips. DOI:10-1094/CM-20050718-01-RS

Eghball B. and Maranville J. W. (1993). Root development and nitrogen influx of corn genotypes grown under combined drought and nitrogen stress. Agron, J. 85: $147-152$.

Hassan R. M., Murithi F. and Kamau G. (1998). Determinants of fertilizer use and the gap between farmers' maize yields and potential yields in Kenya. In Maize technology development and transfer: A GIS application for research planning in Kenya. (R. M. Hassan, ed.) CAB International in Associa- 
tion with International Maize and Wheat Improvement Center (CIMMTY) and Kenya Agricultural Research Institute (KARI).

Khosla R. M., Mark A. and Paul H. D. (2000). Nitrogen management in no-tillage grain sorghum production 1. Rate and time of application. Agron. J. 92: 321-328. (Available from: http://agron. scijournals.org/cgi/content/abstract/92/2/321).

LaFarge T. A. and Hammer G. L. (2002). Tillering in grain sorghum over a wide range of population densities: modeling dynamics of tiller density. Ann. Bot. 90: 99-110.

Ma B. L., Dwyer L. M. and Costa C. (2003). Row spacing and fertilizer nitrogen effects on plant growth and grain yield of maize. Can. J. Pl. Sci. 83: 241-247. (Available from: http://pubs.nrccnrc.gc.ca/aic-journals/2003ab/cjps03/apr03/ cjps02-052.html).

Mafongoya P. L., Bationo A., Kihara J. and Waswa B. S. (2006). Appropriate technologies to replenish soil fertility in southern Africa. Nutr. Cycl. Agroecosyst. 76: 137-151. DOI:10.1007/s10705006-9049-3.

McCown R. L., Keating B. A., Probert M. E. and Jones R. K. (1992). Strategies for sustainable crop production in semi-arid Africa. Outlook Agric. 21: 21-31.

Nielsen D. C. and Halvorson A. D. (1991). Nitrogen fertility on water stress and yield of winter wheat. Agron. J. 83: 1065-1070.

Porter P., Hicks D., Lueschen W., Ford J., Warnes D. and Hoverstad T. (1997). Corn response to varied producer controlled factors and weather in high yield environments. J. Prod. Agric. 4: 51-57.

Rhodes E. R. (1995). Nutrient depletion by food crops in Ghana and soil organic nitrogen management. Agric. Syst. 48: 101-118. DOI: 10.1016/ 0308-521X(95)93648-W.
Sallah P. Y. K., Ehlke N. J. and Geadelmann J. L. (1998). Progress from selection in La Posta maize population evaluated under three nitrogen fertilizer levels. Afr. Crop Sci. J. 6: 241-248.

Shapiro C. A. and Wortmann C. S. (2006). Corn response to Nitrogen rate, row spacing and plant density in Eastern Nebraska. Agron. J. 98: 429_ 535. DOI: 10.2134/agronj2005.0137.

Stoorvogel J. J., Smaling E. M. A. and Janssen B. H. (1993). Calculating soil nutrient balances in Africa at different scales. Fert. Res. 35: 227-235. DOI: 10.1007/BF00750641.

Twumasi-Afriyie S., Sallah P.Y.K., Ahenkora K., Asiedu E., Obeng-Antwi S., Frimpong-Manso P. P., Osei-Yeboah S., Apau A. O., MensahAnsah A., Haag W. and Dzah B. D. (1997). Development and release of three quality protein hybrid varieties. Dadaba, Mamaba and CIDA-ba in Ghana. Kumasi: Crop Research Institute.

Vagen T. O., Lal R. and Singh B. R. (2005). Soil carbon sequestration in sub-Saharan Africa: A review. Land Degrad. Dev. 16: 53-71.

Von Qualen R. H., Yakpayiba P. K. and von Qualen S. K. (1993). Low plant population constraint on maize production in the East Mamprusi district. Third Workshop on improving farming systems in the interior savanna zone of Ghana, Nyankpala, Ghana.

Workayehu T. (2000). Effect of nitrogen fertilizer rates and plant density on grain yield of maize. Afr. Crop Sci. J. 8: 283-294. Available from http:// www.bioline.org.br/request?cs00029.

Yamoah C. F., Bationo A., Shapiro B. and Koala S. (2002). Trend and stability analysis of millet yields treated with fertilizer and crop residues in the Sahel. Fld Crops Res. 75: 53-62. DOI: 10.1016/S03784290(02)00008-4. 